\title{
The Pragmatics of Proverbs in Ola Rotimi's Kurunmi
}

\author{
Olusegun Oladele Jegede ${ }^{a^{*}}$, Eniola Omotayo Osoba ${ }^{b}$ \\ a, b Department of English and Literary Studies, Lead City University, Ibadan, Nigeria
}

\begin{abstract}
This study examined the pragmatics of proverbs in Ola Rotimi's Kurunmi. The study focused particularly on the interpretation of the proverbs used in the text, based on the contexts in which they were used. The study used content analysis as its design, which gave room for a critical analysis of the proverbs in the text. Thirty proverbs were extracted from the text and interpreted based on their contextual use. The findings revealed that the contextual use of proverbs in the text served different role such as warning, commending, insulting, encouraging, abusing, advising, correcting a wrong doing and asserting. The study concluded that proverbs can be best understood when interpreted according to the contexts of their use. Thus, the context of culture and situation help to inform the true meaning of Yoruba proverbs when used in interactions and the knowledge of pragmatics can help linguists, especially pramaticians, to understand and interpret proverbs from any culture.
\end{abstract}

Keywords: Pragmatics; Proverbs; Context; Pragmatic Acts.

\section{Introduction}

Proverbs arise as a result of human experiences in a particular cultural setting (Odebunmi, 2006). Proverbs are very consise, and embedded with philosophical meaning (Ogbulogo, 2002). The cultural background of a people can easilly be determined through their proverbs. It helps explain a people's historical development, perspectives about life, and attitude. Proverbs help to control social behaviour and ensure mutual intelligibility among interlocutors (Yusuf \& Methangwane, 2003). They are used to disseminate sensitive or vital messages in a libral way. Proverbs, being highly philosophical in nature, attracts the attention of Nigerian writers such as Chinua Achebe, Zulu Sofola, Zainab Alkali, T. M. Aluko, and Ola Rotimi among others.

As good as proverbs are, their meanings and applications can best be determined in context (Odebunmi, 2008; Fashina, 2011; Raji-Oyelade, 2004). Context is the situation or events surrounding the use of the proverbs. Thus, pragmatics is very inportant in the aanalysis and interpretation of proverbs. Pragmatics deals with the study of meaning based on context. Put succinctly, the meaning of an utterance, in this case, proverbs, is determined by the situations surrounding the utterance (proverbs).

Examining the interrelatedness of proverbs, pragmatics and context, this study aims to examine selected African proverbs used by Ola Rotimi in Kurunmi. The contexts in which the proverbs are used are considered in order to determine the meanings of the proverbs. The functions of the proverbs are also discussed and the relevance of the proverbs to the messages of the text is also established.

\footnotetext{
* Corresponding author 


\section{Literature Review}

\subsection{The Pragmatics of Proverbs}

According to Birner (2013), pragmatics may be roughly defined as the study of language use in context. He observes taht the study of pragmatics looks at such interpretive regularities and tries to make explicit the implicit knowledge that guides us in selecting interpretations. Mey (2001) observes that pragmatics is the science of language seen in relation to its users. That is to say, not the science of language in its own right, or the science of language as seen and studied by the linguists, but the science of language as it is used by real, live people, for their own purposes and within their limitations and affordances. According to Huang (2007), pragmatics is the systematic study of meaning by virtue of, or dependent on, the use of language. Similarly, Verschueren and Ostman (2009) view pragmatics as the investigation into that aspect of meaning which is derived not from the formal properties of words, but from the way in which utterances are used and how they relate to the context in which they are uttered. Leech (2014) defines pragmatics as the study of meaning in relation to speech situations. The speech situation enables the speaker use language to achieve a particular effect on the mind of the hearer (Yule, 2002). Ariel (2008) also sees pragmatics as the study of those aspects of the relationship between language and context that are relevant to the writing of grammars. Yule (1996) defines pragmatics simply as the study of intended speaker meaning in relation to context.

We will observe in these definitions that focus is on the inter-relation of language and principles of language use that are context dependent. We will also notice that there some common features in the definitions that will help us understand better the principles of pragmatics in relation to proverbs.

The first feature is language use. This has to do with language in actual speech situations. Proverbs involves the use of language in actual speech situations (Ehineni, 2016a; Ehineni, 2016b). They are less meaningful outside speech situations. Thus, what is important is how language users use proverbs to communicate in oral conversations or in writing to achieve their communicative goals.

The second feature is the context of the speech. This involves the physical location of participants in a conversation, the time of the conversation, the language of communication, the socio-cultural setting, the psychological state of the interlocutors, and the institution of discussion. These features of context are very important to our use and understanding of proverbs. They help us interpret proverbs and apply them to our daily activities.

The third feature, goal of utterance or speaker's intention, is very important to the interpretation of proverbs. Proverbs are products of the goals of utterances or speaker intention (Alimi, 2012). In other words, what a speaker wants to achieve with a particular utterance will determine the kinds of proverb he will choose.

The fourth common feature points to the participants in a conversation or discourse situation. The roles of the participants in the communicative process are very important. In the African setting, when a conversation is going on between an adult and a young person, the adult alone has the right to speek in proverbs. It is considered rude for a younger person to speak in proverbs before an adult. However, adults can speek freely to other adults in proverbs. The relationship between participants and their identities are also very important in the use of proverbs since these have influence on how meanings are encoded and interpreted.

The fifth common feature of pragmatics is shared knowledge, culture, or conventions of participants in communication. This feature is very important in the understanding of proverbs. The participants must both have a good knowledge of the proverb; they must be from the same cultural background and share the same life style (Gogoi, 2017). Our knowledge of pragmatics is very important to our interpretation and understanding of proverbs.

\subsection{Review of Studies on Proverbs}

Odebunmi (2006) examines three recent dramas by Ahmed Yerima - Attahiru, Dry Leaves on Ukan Trees, and Yemoja. He finds that Yerima uses proverbs primarily as communication tools within culturally defined contexts, such that a function-based, rather than a structure-based, approach must be taken to properly understand their role in the dramas. He uses a modified model of pragmatics for understanding the role of the proverbs, based on Mey's 2001 model of a pragmeme. His study demonstrates that Yerima's plays employ proverbs with topic/comment, fixed/non-fixed, and poetic/non-poetic structures, and that they include all three types of proverbs-weather, flora/fauna, and cultural. Most importantly, it is found that the proverbs are sensitive to contexts of interaction. Through proverbs, the speakers in the dramas use pragmatic acts, or practs which counsel, accuse, pronounce, and/or assure. The proverbial propositions are reformulated by the speaker to unveil their meanings, allowing readers, whether or not they are members of the culture, to fully access the dramas. This study on Yerima's plays aims to shift the literature on pragmatics forward while simultaneously providing new insights into contemporary African drama.

Odebunmi (2008) examines the pragmatic functions that crisis-motivated proverbs play in Ola Rotimi's The Gods is not to Blame. It picks its inspiration from the little attention hitherto paid, in the linguistic literature, to both the specific proverbs that are spurred by crisis in the play and the pragmatic roles of such proverbs. He 
chooses only the proverbs that are necessitated by the crisis-situations in the text as samples, and these are analysed, using Mey's (2001) theory of pragmatic acts. The study reveals that crisis-motivated proverbs in The Gods are not to Blame, which are of two types: social and political, are characterized by practs such as those of counselling, cautioning, challenging, veiling, persuading, prioritizing, encouraging, threatening and admitting. These are psychological acts which exploit contextual features such as reference, metaphor, inference, shared situation knowledge, shared cultural knowledge and relevance. The study concludes that studying literary proverbs used in crisis situations, from a pragmatic perspective, both throws additional insights into the paremiological pool and promises to provide a veritably helpful tool for language teaching.

Fashina (2011) carries out a counter-discourse that hopes to subvert the critical mediations that deify the 'mid-wifery' role of proverbs in narrative communication, especially in Achebe's fiction. Although, he recognizes the place of historical and philosophical truth, archetypal wisdom, and rhetorical 'force' in proverbs, he argues that this numeric density of figurative residents of proverbs is a burden of semantic ambiguity and narrative sublimation. Annexing the resources of critical theory, logic and linguistic analysis, his study takes intrinsic look at Things Fall Apart, and diagnoses the relations of proverbs to the narrative in terms of their categories of sublimation devices of Exclusive/Diacritical, Inclusive/Taxonomic and Intersectional/Semantic values. Thus, proverbs have overt aesthetic and affective functions; but they are never the less meta-narrative/meta-poetic discourses on the borderline of nonsense and grammar, and as such their nuggets of wisdom and logic may blinker us from the reality of their 'states' as neuro-psychic specimens requiring the services of neuro-linguists to decipher. The study, however, insulates itself from value judgment by not being prescriptive or legislative about the negative or positive values of proverb usage in discourse and necessity for proverbial listing in narratives and other communication. Rather, it is descriptive, stressing that proverbs are strategic instruments of semantic deflection, diffusion, and distraction from the pseudo- temporal nature of language. To the speaker of proverbs, they are verbal, nuclear weapons of rhetoric, style and communicative 'force' with telepathic functions. They are a meta-force that disarms the hearers from resisting the verbal order (and pragmatic authority) and internal 'law' of reason that govern discourse or communication. His study concludes that proverbs compel psychic and philosophical obedience from their hearers; for the latter is seemingly bound by their mega discursive power to succumb to the speaker's ideational proposition, logic and the otherwise prescriptive rules encapsulated in the proverbs.

Ehineni (2016a) attempts a discourse and structural analysis of Yoruba proverbs collected from oral interviews and native Yoruba texts. First, based on a theory of the proverb as a discourse medium, the study reveals that proverbs are used to achieve different discourse acts and communicative goals by speakers. Native speakers use the proverb as a linguistic strategy of negotiating deep ideas and intentions. Second, the study avers that the Yoruba proverb is structurally characterized by some lexical and grammatical devices which help to reinforce its communicative intelligibility and textuality. Thus, it examines the Yoruba proverb both functionally and formally and underscores that it is a culturally and linguistically rich significant part of the Yoruba speech community.

Ehineni (2016b) examines the pragmatics of Yoruba proverbs in Ahmed Yerima's plays, Igatibi, Ajagunmale, and Mojagbe. The study is motivated by the ingenuous deployment of Yoruba proverbs to facilitate effective communication and interaction in the plays. The proverbs are analyzed using the theory of pragmatic acts (Mey, 2001) and the theory of proverb praxis (Yankah, 1989). The study reveals that proverbs are used in the selected plays for different pragmatic purposes including supporting, warning/cautioning, questioning/querying, reassuring, defending, and accusing, which exploit contextual features such as relevance, reference, metaphor, inference, shared situation knowledge, shared cultural knowledge, and voice. The study concludes that the context of culture and situation help to inform the true meaning of Yoruba proverbs when used in interactions.

Gogoi (2017) studies Chinua Achebe's use of proverbs in Things Fall Apart and No Longer at Ease. He finds that Chinua Achebe creatively uses oral cultural elements such as proverbs, folktales and myths to convey different messages. His use of Ibo proverbs reveals his strategy to make a foreign language his own and his endeavour to make it express African sensibilities. His dexterity in the use of proverbs lies in the way he manipulates their application to suit the different social, cultural and political contexts portrayed in the novels. He uses them skilfully and in a restrained manner so that they do not appear imposed and forced. Proverbs used in Things Fall Apart, a novel set in a rural oral society and in No Longer at Ease, a novel set in an urban literate society mark how Achebe's handling of the African oral cultural element is not mechanical, but strategic and highly manipulative.

Alimi (2012) studies the use of proverbs as a literary device in Achebe's Things Fall Apart and Arrow of God. He studies how Chinua Achebe uses proverbial language to describe his character's appearances, actions, habits, inner feelings and thoughts. He performs a critical appraisal of the proverbs in the novels and submits that Achebe uses proverbs as a tool for delineating his characters in the two novels.

\section{Methodology}

The study adopted content analysis as its analytical method. Content analysis is based on interpreting opinions and perspectives of various subjects. Content analysis helps to examine patterns in communication in a replicable and systematic manner. Applying this method enabled us to interpret opinions and perspectives presented 
through proverbs in Ola Rotimi's Kurunmi. Through this method, we were able to examine the patterns (functions and dimensions) of proverbs used in the text. All the texts written by Ola Rotimi are rich in proverbs. However, Kurunmi has the most proverbs. The text was critically read and thirty proverbs were extracted from it. The the proverbs were then interpreted based on the context in which they were used in text. The analytical framework used for the analysis of data was Mey's (2001) Pragmatic Acts theory.

\section{Data Analysis and Discussion}

\subsection{Analysis of Proverbs in Ola Rotimi's Kurunmi}

PROVERB 1: “When an Elder sees a mudskipper, he must not afterwards say it was a crocodile” (p. 42).

Generalissimo Kurunmi utters this proverb in his Ogbole (palace of a kind) to some of his warriors. Kurunmi's fellow warriors complain about his autocratic and overbearing attitude. They complain about his unilateral decisions to take them to war instead of seeking their opinions. This time in particular, he has resolved to resist Prince Adelu's plan to succeed his father as the Alafin of Oyo without consulting them. They threaten to dump him as their leader and send some warriors to take the message to him. In response, he promises them a change of attitude and by this proverb he impresses on the men to take him at his word and convey exactly what he has said to the other warriors. The proverb is reassuring in tone and teaches that an elder, by virtue of his age should not lie.

PROVERB 2: "It is a foolish daughter who thinks she knows so much that she can teach her own mother how to bear children" (p. 64).

In an atmosphere of despair resulting from the defeat of Ijaiye and Egba fighters by Ibadan warriors, Kurunmi, reprimands one of is warriors for disregarding his commander's instruction. Ijaiye soldiers were warned by their commander, Ogunkoroju, not to pursue their enemies but the warrior gave a contrary directive which led to the loss of many Ijaiye warriors. As a mother is naturally more experienced than her daughter in child bearing, so is a military commander necessarily better trained and more tactical in war strategies than a mere soldier. Spoken in the presence of Ogunkoroju and other warriors in Ijaiye war camp, the tone of this highly didactic proverb is strong and it instructs that wisdom is greater than strength.

PROVERB 3: "The bull-frog that rivals the size of the elephant will burst" (p. 29).

As the news is heard that Adelu succeeds his father as Alafin of Oyo, Kurunmi expresses his displeasure before warriors Balogun, Areagoro and Ogunkoroju. The warlord is not happy that Oyo broke tradition by making Adelu to succeed his father when tradition demands that he (Adelu) should die with his father. To worsen the matter, Ibadan that should know better, supports Oyo in the abominable act. The elephant in the proverb is Kurumi while the bull-frog is Oyo. Spoken by Kurumi in his Ogbole, the tone of the proverb is sarcastic and implies that when you challenge somebody stronger or bigger than you to a combat, you must be prepared to face the consequences. PROVERB 4: "The young palm tree grows tall rapidly, and it is proud, thinking, hoping that one day it will scratch the face of the sky. Have its elders before it touched the sky?" (pp. 35-36)

Rev. Mann meets Kurunmi in his Ogbole to complain that the people of Ijaiye are not responsive to the gospel, unlike their counterparts, Oyo and Ibadan. He therefore appeals to Kurunmi to lend his support so that the gospel can make headway in Ijaiye. In response, Kurunmi directs this proverb at him (Rev. Mann) to warn him against joining others to uproot the tradition of his (Kurunmi's) fathers. The young, proud, growing palm tree that hopes to scratch the sky in the proverb symbolizes the gospel that Rev. Mann talks about. The tone of this proverb laden with philosophical ideology is threatening. It cautions that when one tries to do something forbidden or unprecedented one must be wise and ready to first make proper enquiry.

PROVERB 5: "The Gabon ripper dies; its children take up its habit, poison and all. The plantain dies; its saplings take its place, broad leaves and all. The fire dies, its ashes bear its memory with a memory of white fluff" (p. 15). Kurunmi is displeased that Adelu is to succeed his father as the Alafin of Oyo. In fury, he speaks this proverb in his Ogbole to some elders, warriors and a crowd. By this proverb, Kurunmi sensitizes the people on the importance of tradition and the need to maintain and preserve it. The proverb is both philosophical and analytical and the tone is strong. The opinion of Kurunmi expressed in the proverb is cruel, proud and recalcitrant but does not realize it. Ibadan warriors who are fellow warriors of Kurunmi in the Oyo kingdom are therefore in a position to "...see his (Kurumi's) ugly buttocks" (show him his weakness) by humbling him in a fierce battle. The message communicated by the proverb is that one cannot correctly assess his character. Instead, it requires another person to do that objectively and correctly.

PROVERB 6: "When five little hyenas combine strength they crush the father of lions" ( p. 38).

In Kurunmi's Ogbole, the Ijaiye warriors express their dissatisfaction with Kurunmi's unilateral decision to go to war against Oyo for the proposed succession of the late Alafin by his son, Adelu, who Kurunmi insists should die with the father according to the tradition. Epo, one of the Ijaiye warriors, warns Kurunmi by this proverb, that he (Kurunmi) could be defeated by the combined efforts of the warriors who are displeased with his autocratic leadership. The tone of the speech is serious and the atmosphere is tensed. This proverb, which is analogous to the English maxim "United we stand, divided we fall", means that a people become very strong and indomitable when 
they combine their resources and strength. It serves the communicative purpose of preaching unity and singleness of purpose among groups of individuals.

PROVERB 7: "Does the aged he-goat have to be told that his present long beard is no more proof of sexual strength?" (p.18)

As Kurunmi's opposition of late Alafin's succession by his son, Adelu, draws the attention of Oyo kingdom elders, they send elders Timi, Asegbe, Arawole and Oluyole to come around to Kurunmi's palace to warn him not to do anything against the kingdom. Kurunmi is however defiant and utters the proverb in response. By this rhetorical proverb, Kurunmi disdains the elders for supporting Adelu's ascension to the throne of Alafin instead of standing against it. The speech means that age loses its value with time especially if it is afraid of standing for truth and right. The expression is a proverb that slams presumption, pretentious and overconfidence.

PROVERB 8: "The cow defecates and thinks she is soiling the pasture; we shall see whose buttocks get soiled first" (p.21)

The proverb is the parting word of Oyo elders to Kurunmi in his compound. Uttered by Timi, one of the elders, and in an atmosphere of bitterness and anger, the proverb warns Kurumi of the repercussion of doing anything to stop Prince Adelu from becoming the next Alafin of the kingdom. Timi cautions that as the cow in the proverb defecates and soils its own buttocks, so will Kurunmi harm himself if he attempts to oppose Adelu. The speech is an adage spoken with a harsh tone and means that one who throws the mud comes out with a soiled hand. The proverb then serves the purpose of warning people against attempting to hurt others because they may end up harming themselves.

PROVERB 9: “A cow is about to be shipped to Whiteman's land and she is happy. Very happy Ehn ... let the cow go. When she gets to Whiteman's land, what will she become? C-o-r-n-e-d b-e-e-f!" (p.22)

Still in Kurunmi's compound, Kurunmi and elders Timi, Asegbe, Arawole and Oluyole trade words. Kurunmi insists on his resolve to resist the emergence of Adelu as the next king even as the elders fail to convince him not to oppose the plan. Kurunmi insists that tradition must be maintained so that when a king dies, the prince dies with him. The tone of this proverb by Kurunmi is cynical and it implies that one may be heading for his doom and yet think he is on his way to paradise. The cow that is about to be shipped to a Whiteman's land and is happy is Prince Adelu who is about to be made king contrary to tradition and he is happy. The expression is a dictum that warns against false hope and self delusion.

PROVERB 10: "A man with fire on his hands welcomes no delay" (p.28)

Prince Adelu, on ascending the throne as the new Alafin of Oyo Empire, sends to Kurunmi to choose between peace and war. Kurunmi chooses war in the presence of two Ijaiye warriors, Oje and Lakusa, who were with him in his Ogbole when the messenger came from Oyo. Now in a war mood Kurunmi sends Lakusa to Egba to ask for their support in the imminent war. He utters this proverb to impress on the messenger the urgency of the message. Lakusa understands the import of the proverb and speeds off to deliver the message. The tone of the speech is urgent. It means that one does not lazy about when war or trouble is at his doorstep. It is a cliché calling for urgency in the face of trouble.

PROVERB 11: “A man who does not want strange foot-prints in his backyard must fence it up" (p.29).

In Kurunmi's compound, Kurunmi, Balogun, Areagoro and Ogunkoroju are in war mood. Kurunmi persuades them to resist the move to make Adelu succeed his father. The warriors accept to resist the move and Kurunmi is making necessary arrangement preparatory to successfully executing the imminent war. The tone of the speech is solemn. By the proverb, Kurunmi means that one must do something to get what one wants or reject what one does not want, just as a man who does not want strange foot-prints in his backyard must fence it up. Kurunmi and Ijaiye people do not want the age-long tradition of the Oyo Empire broken, so they must do something and that urgently, to stop Adelu and Oyo people from doing so. The proverb communicates the need for action.

PROVERB 12: "The meat of an antelope tastes good, but while it is cooking what do we eat?" (p.30)

Still in Kurunmi's compound, preparation for the looming war is ongoing. Kurunmi spurs his co-warriors, Balogun, Areagoro and Ogunkoroju to action. Ogunkoroju is persuaded to fight in the war against Alafin Adelu. The tone of the proverb is persuasive. It implies that preparation is necessary for any good thing one is expecting. Kurunmi and other Ijaiye war lords must make proper preparation to prevent poor performance in the imminent war. Just as the meat of an antelope tastes good, but while it is cooking something must be eaten, so is peace good, but while it delays to come, something must be done-war must be fought! The proverb communicates the need for one to be proactive.

PROVERB 13: "A goat gets wiser after an ear is cropped off" (p.32)

As the preparation for the war is gathering momentum, news come to Kurumi in his Ogbole that Ibadan will fight on the side of Oyo. Kurunmi assures himself that he will defeat the combined forces of Oyo and Ibadan. The proverb is a monologue spoken in a cynical tone. It insinuates that unwise persons learn their lessons after suffering for their stupidity. Kurunmi assures himself that impudent Ibadan and Oyo will learn the lesson of their lives after he (Kurunmi) will have dealt with them in the war, just as a foolish goat gets wiser only after its ear is cropped off. An English proverb close to this in meaning is "Once bitten, twice shy". The proverb communicates the need for prudence in life.

PROVERB 14: "When a rat laughs at a cat, there is a hole nearby" (p.38)

In Kurunmi's compound, apprehension pervades the air. Some Ijaiye warriors register their displeasure to Kurunmi. They are not happy about his unilateral decision to fight Oyo. The warriors declare that they are not 
afraid of him. Kurunmi is dumbfounded by their effrontery and concludes that as a rat laughs at a cat because a hole is nearby, so have the warriors challenged his authority because they rely on help from somewhere. The tone of the proverb is confirmatory. It means that when a weak person challenges someone stronger than him to a duel, then there is help around the corner. The expression is an adage that explains that there is always a reason for audacious behaviour.

PROVERB 15: "He who despises smallness let him step on a needle" (p.41)

In his compound, Kurunmi expresses his confidence in the Ijaiye warriors. He speaks this proverb to assure the warriors that Ijaiye will without fail defeat Oyo and Ibadan in the impending battle. Ijaiye may be small compared to the large size of Ibadan and Oyo combined. After giving gifts to the warriors to win them to his side, Kurunmi speaks to convince them that the decision to go to war will not be regretted. The tone is reassuring and implies that someone or something can be small but dangerous. Ijaiye may be small but you do not step on a needle because it is small; if you do, you regret it. Are-ona-kakanfo Kurunmi boasts that Oyo and Ibadan must regret fighting small Ijaiye. The proverb is philosophical. It serves the purpose of warning people against despising smallness.

PROVERB 16: "A man cannot be so angry with his own head that he seizes the cap from that head and dons his buttocks with it" (p.46)

In Ibadan camp, the council of elders and warriors hold discussions on whether to go to war against Ijaiye or not. Some of the warriors favour war while others disapprove of it. In particular, Elder Ibikunle advises against war, because, according to him, Oyo, Ibadan and Ijaiye are one and therefore, the option of war is ruled out; but Ogunmola insists on war. The tone of the proverb is mild and teaches that one does not hurt himself because he or she is angry. Ibikunle feels that Oyo, Ibadan and Ijaiye are like the eyes, nose and mouth on the same face and fighting Ijaiye is tantamount to fighting oneself, the degree of provocation notwithstanding. The proverb serves a communicative purpose of recommending brotherhood and condemning schism.

PROVERB 17: "No matter how high the swallow flies it must at last come down to earth"(p.47)

Still in Ibadan camp, intense discussions continue on whether to go to war against Kurunmi or not. Ibikunle tries to dissuade the elders from considering the option of war but Ogunmola and some other warriors refuse to be dissuaded. The Ibadan warriors are angered by Kurunmi's rude insistence on fighting Alafin Adelu. The tone of the proverb is mild. It means that what goes up must come down just as the swallow that flies up must at last come down to earth. This is an allusion to the law of gravity. By this proverb, Ibikunle advises peace because he believes that Kurunmi's anger which is high now will certainly abate. The proverb proclaims the need for patience with fellow men as what is up today will be down tomorrow and what is hot today will be cold tomorrow.

PROVERB 18: "Secrets of the mouth are first known to the chewing stick. Secret of the palm wine are first known to the fly. Secret hidden in the footpath are felt by the sole of the feet" (p.59)

In Ijaiye, the warriors are set for war against Ibadan. Balogun Ogunkoroju appeals to the gods for help in the pending war. He prays to Ogun and Sango for their support before the war begins. The tone of the proverb is soft. Traditional African people believe that the land of the living is not far removed from the domain of the ancestors who are said to be omnipresent, omnipotent and omniscient. As the secrets of the mouth are known to the chewing stick; secrets of the palm wine known to the fly and secrets hidden in the footpath felt by the sole of the feet, so is the result of imminent war known to the gods. The proverb underscores the necessity of submission and recourse to supernatural powers.

PROVERB 19: "Because of the deaf, the clouds blacken before it rains; because of the blind, thunder rumbles" (pp.59/60)

In Ijaiye camp, Balogun Ogunkoroju continues his appeal to the gods for help in the looming war on behalf of the rest of Ijaiye fighters. The warriors offer prayer to the deities, Ogun and Sango, for their support in the forthcoming war. The proverb has a mild tone. The gods are believed to be merciful; so, needy persons ask for help from them. In particular, the gods are disposed to showing their mercies to handicapped persons and they ensure there are clouds before it rains to warn the deaf and thunder to alert the blind. Apart from that, they also reveal future events, good or evil to those who consult them. This is the focus of the warriors' prayer-to catch a glimpse of the outcome of the war. The proverb brings to the fore the benevolence and omniscience of the gods.

PROVERB 20: "Sharp though a knife, it cannot cut its own handle"(p.60)

In a war mood, Ijaiye warriors continue to pray to the gods. It shows that the warriors do not rely on their own strength or on the sophistication of their weapons for victory in the forthcoming war. The tone of the proverb is mild. It implies that it is difficult and perhaps impossible for one to harm himself deliberately. By this speech, Balogun Ogunkoroju reminds the gods that they (the people of Ijaiye) belong to them (the deities) and as a knife cannot cut its own handle no matter how sharp it is, so will the gods not harm the Ijaiye warriors, no matter how angry they are with them. The proverb stresses divine ownership of humans and the need for total dependence on providential care.

PROVERB 21: "There is no god like the throat; it takes sacrifice daily" (p.60)

Warrior Areagoro takes his turn in the prayer to the gods. He takes over from Balogun Ogunkoroju to solicit for divine help in the upcoming war. The tone of the proverb is soft. The speech is metaphoric as it compares the food that passes through the throat daily to the food and other items given in sacrifice to the gods in traditional African society. It is believed that the gods can be appeased with gifts varying from money to food items and cloths when they are displeased with humans. Gifts are also used to solicit their help in times of need, in this case, the need for 
victory in war. The proverb is a rhetorical presentation of the prayer of a traditional African worshipper seeking divine assistance.

PROVERB 22: "A man with grass on his buttocks must not forget himself when he goes to put out a neighbour's fire." (p.74)

Egba warriors arrive Ijaiye to help in the war against Ibadan. Somoye, one of the Egba warriors, impresses on Kurunmi the need for urgency in executing the war. He asserts that Egba is like a man with grass on his buttocks who must not forget himself when he goes to put out a neighbour's fire. The Egbas have their own challenges; the people of Dahomey have threatened to invade their land. So, it will be foolishness on their part to come to help Ijaiye and stay unnecessarily long. The tone of the proverb is persuasive and implies that those susceptible to danger must always be wary. The proverb serves a communicative purpose of teaching wisdom and watchfulness even in helping others.

PROVERB 23: "When a one-legged man needs help, he must not say that the friend who carries him on his back stinks; even if that helper does stink" (pp.83-84)

In Kurunmi's Ogbole, the battle grows sore against Kurumi and Ijaiye fighters. The two groups suffer a huge loss in the ongoing war as thousands of soldiers lose their lives. A Bodyguard blames the Egbas for the poor performance of the Ijaiye and Egba soldiers. Kurunmi, however, advises the Bodyguard by this proverb, not to criticize the Egbas. The tone of the proverb is solemn and states that it is unreasonable for a helpless person to find fault with one who only offers to help him or her. Ijaiye needed help and so requested Egba to help out. The fact that the war is not in their favour is not reason enough to blame their helpers. The proverb is didactic and teaches that one should not blame his sincere helper for his woes. Also, you must tread with care when you have something at stake.

PROVERB 24: "A man called upon to be a hawk must catch chicken". (p.85)

Ogunmola telling Ibikunle that they came to fight not celebrate he is saying it so that They can fight and get victory and he said let them fight what there is to fight and return to Ibadan at once Ibikunle told him he expects too much, my brother you forget it is Kurunmi himself we fight. The Areonakakanfo's quick victory by arm is not so easy.

PROVERB 25: "When a child is a failure in life, the mother bears the blame; when the child succeeds, the credit naturally goes to the father". (p.74)

Ogunmola swears to get victory wiping Out Egbaland after levelling the land of Ijaiye Sanoye to Ogunmola. The proverb is used to motivate Ogunmola. Because they have always had victory whenever they go for war and this particular one seems to be very difficult because Kurunmi was involved and they pray for the war not to be a curse of mothers so that they can get victory.

PROVERB 26: "The hawk yearns for the taste of the snail but it forgets the shell of the snail is no food for Hawks". (p.87)

The warriors talking to each other to motivate themselves and referring to the Oyos that even if the Oyo and Ibadan think they can have victory over them because they have more soldiers but unknowingly to the Oyo and Ibadan soldiers the Ijaiye soldiers have a better weapon that will not allow the Oyo and Ibadan soldiers have victory over the Ijaiyes.

PROVERB 27: "Ten eyes, twenty eyes, countless eyes of others are not the same as a single eye of your own". (p.88) 'Our failure is not for sharing with others, our failure is our own, our shame, our death,' Kurunmi tells the warriors. He continues, this is a day we know whether we live or die, It is our task. Kurunmi said the soldiers of Egbas cannot help the Ijaiye save the Ijaiye land that they can only support but cannot fight like the true blood of Ijaiye soldiers so they should not count on Egba warriors and fight to victory.

PROVERB 28: "When an elder sees a mudskipper he must not after words say it was a crocodile". (p.42)

Kurunmi says his word is his word nothing changes he stands by his own words and swears that he shall seek the elders of ijaiye for counsel in any action he wants to take and ask the elders to forgive his actions. The elders agreed and approved what he said and they said nothing shall again separate them from oneness. They all lean forward and grab the sword, sanctifyingtheir oath.

PROVERB 29: "The baby who cries to stop its mother's sleep too will suffer the anguish of not sleeping". (p49.)

Ogunmola says the above proverb to the crowd of the young warriors saying it to anyone who tries to bring him harm. The proverb serves as a warning; Ogunmola is warning that if they are looking for who to be forced to go to war with Kurunmi, they should go and look for scape goat somewhere, and that no one should call his name into the matter again because he has nothing to do with it anymore. And that anyone that talks evil against him, it is unto his own head the evil will return same goes to he who plot with another to bring him harm.

PROVERB 30: "A stick already touched by fire is not hard to set ablaze". (p.48)

Ibikunle to the warriors that they must deal softly with Kurunmi because of his anger Ibikunle continued by saying they must deal softly with Kurunmi, that must try to win him not by violence, not through battle songs. Just peace to rain in the land and the people's heart. The warriors are still not satisfied with what Ibikunle has said because they know how dangerous Kurunmi can be. Then Osundina said they should be patient with Kurunmi because he is a man full of years and not long from now, he will be gathered into the land of the silence. Then they can have in Ijaiye another leader whose ear will receive their words and pay homeage to the new Alafin. 


\subsection{Findings and Discussion}

The findings reveal that the proverbs used in the play expressed intellectual and emotional attitudes. They performed roles such as giving advice, approval, disapproval, appreciation, apology and regret. They also performed socialising and persuasive functions. Some of the proverbs were used to congratulate, attract attention, advise, offer suggestions, request and warning. The meanings generated by the use of these proverbs usually depended on the situations or circumstances in which they were used. That supports the favt that proverbs are context dependent, and it is difficult to determine the meaning of a proverb without the context in which it is used.

The study also shows that the use of proverbs relies heavily on tribes, races and cultures. Therefore, proverbs are rooted in a people's philosophy, religion and cosmology. In the text, Rev. and Mrs. Mann do not use any proverb throughout in the text because they ddo not share the same socio-cultural context with others. Another obvious result of this investigation is that, although proverbs have usually been considered the preference of the elders in the society because they are seen as the repository of the wisdom of the race, the elders may not necessarily mean those who have advanced in age. There are those who have responsibilities and positions of elder entrusted on them by status and they discharge such duties as such. Young kings and chiefs fall into this category.

\section{Conclusion}

In conclusion, proverbs, as used in the play, depict wisdom, practicality and efficiency in speech. By their nature, proverbs portray politeness in cases where a direct speech may sound offensive or rude. The linguistic effect of proverbs reaches deeper into the human mind than mere words. They also show the maturity and experience of the speaker because their use calls for a measure of patience and decorum. Proverbs are not used for aesthetic purposes alone but also to improve the overall comprehension of what is said. Ola Rotimi uses proverbs in the text to garnish discourse, foreground issues, emphasize points, project the culture and portray the worldview and philosophy of the Yoruba race. Thus, the context of culture and situation help to inform the true meaning of Yoruba proverbs when used in interactions and the knowledge of pragmatics can help linguists, especially pragmaticians, to understand and interpret proverbs from any culture.

\section{Biography:}

Olusegun Oladele Jegede is a lecturer in the Department of English and Literary Studies, Lead City University, Ibadan, Nigeria. His research areas include Pragmatics, Syntax and Applied linguistics. He has a number of publications in these areas.

Eniola Omotayo Osoba is a member of the Department of English and Literary Studies, Lead City University, Ibadan, Nigeria. Her research areas include Pragmatics and Semantics.

\section{References:}

[1] Alimi. S. A., A Study of the Use of Proverbs as a Literary Device in Achebe's Things Fall Apart and Arrow of God, International Journal of Academic Research in Business and Social Sciences, 2(3)(2012), 121-127.

[2] Ariel. M., Pragmatics and Grammar, Cambridge: Cambridge University Press, (2008)

[3] Birner. B. J., Introduction to Pragmatics, United Kingdom: Blackwell Publishing, (2013)

[4] Ehineni. T. O., A Discourse-Structural Analysis of Yoruba Proverbs in Interaction, Colombia Applied Linguistics Journal, 18(1)(2016a), 71-83, https://doi.org/10.14483/calj.v18n1.9660

[5] Ehineni. T. O., The Pragmatics Of Yoruba Proverbs In Ahmed Yerima's Igatibi, Ajagunmale, And Mojagbe, Issues in Intercultural Communication, 4(1)(2016b), 61-71.

[6] Fashina. N. O., Proverbs and Linguistic Meta-Criticism: Towards a Re-reading of Proverbs as Narrative Sublimation in Achebe's Things Fall Apart, Journal of the Linguistic Association of Nigeria, 14(2)(2011), 283295.

[7] Gogoi. G. (2017), A Study on Chinua Achebe's Use of Proverbs in Things Fall Apart and No Longer at Ease, IOSR Journal of Humanities And Social Science (IOSR-JHSS), 22(12), 52-56.

[8] Huang. Y., Pragmatics. Oxford: Oxford University Press, (2007) 
[9] Leech. G., The Pragmatics of Politeness, Oxford: Oxford University Press, (2014)

[10] Mey. J. L., Pragmatics: An Introduction (2nd ed.), Oxford: Blackwell, (2001)

[11] Odebunmi. A., A Pragmatic Reading of Yerima's Proverbs in 'Yemoja Attahiru' and 'Dry Leaves on Ukan Trees, Intercultural Pragmatics, 3(2)(2006), 153-170, https://doi.org/10.1515/ip.2006.010

[12] Odebunmi. A., Pragmatic Functions of Crisis-Motivated Proverbs in Ola Rotimi's The Gods Are Not to Blame. Linguistik Online, 33(1/08)(2008), 73-84

[13] Ogbulogo. C., Proverb as Discourse. The Example of Igbo Youth and Culture Heritage, Journal of Cultural Studies, 4(1)(2002), 37-49, https://doi.org/10.4314/jcs.v4i1.6189

[14] Raji-Oyelade. A., Posting the African Proverb: A Grammar of Yoruba Postproverbials, or Logophagia, Logorrhea and the Grammar of Yoruba Postproverbials. Proverbium, 21(2004), 299-314.

[15] Rotimi. Ola. R., Kurunmi. Ibadan, Ibadan University Press, (1971)

[16] Verschueren. J. \& Ostman. J., Key Notions for Pragmatics. Amsterdam: John Benjamen publishing Company, (2009)

[17] Yule. G., Pragmatics, Oxford: Oxford University Press, (1996)

[18] Yule. G., A Study of Language, Cambridge: Cambridge University Press, (2002)

[19] Yusuf. Y. \& Methangwane. J., Proverbs and HIV/AIDS. Proverbium, 20(2003), 407-422. 